\title{
Pengaruh Empati Dan Trust Terhadap Friendship Quality Pada Aremania
}

Ahmad Soni Saputro
Sonisaputra20@gmail.com

\author{
Rika Fuaturosida \\ Fuaturosida1@gmail.com
}

\section{Fakultas Psikologi, Universitas Islam Negeri (UIN) Maulana Malik Ibrahim Malang, Indonesia}

\begin{abstract}
The majority of the news provides information about the riots that occurred between supporters but in addition to the conflict between supporters, there is also a strong friendship. If the supporters make peace without clashing will bring a sense of friendship between supporters and have a positive impact. Friendship quality supporters can be reviewed from the feeling of empathy and trust given to fellow supporters. The feeling of empathy can understand the feelings of other supporters and the emergence of mutual trust in each other and it can foster friendship quality between supporters. This research aims to determine the influence of empathy and trust on the friendship quality of Aremania. The Purposive sampling technique used this research with the subject of a number of 126 Aremania has the criteria of ever watching live football matches at the stadium. The results of the research are known that there is an influence between empathy and trust towards friendship quality on Aremania with an $F$ value of 33,173 with a signification value of $0.000(\mathrm{P}<0.05)$. Empathy and trust have an effect on friendship quality of $35 \%$. The high empathy and trust of Aremania can improve the friendship quality of Aremania and the public in general.
\end{abstract}

Keywords: aremania; empathy; friendship quality; trust.

\begin{abstract}
Abstrak
Mayoritas berita memberikan informasi mengenai kerusuhan yang terjadi antar suporter namun selain konflik antar suporter, terdapat juga terjalinnya persahabatan yang kuat. Jika suporter berdamai tanpa bentrok akan memunculkan rasa persahabatan antar suporter dan memperoleh dampak positif. Friendship quality suporter dapat ditinjau dari bagaimana perasaan empati dan kepercayaan yang diberikan pada sesama suporter. Adanya perasaan empati dapat memahami perasaan suporter lain serta munculnya rasa saling percaya satu sama lain dan hal tersebut dapat menumbuhkan friendship quality antar supporter. Penelitian ini bertujuan untuk mengetahui adanya pengaruh empati dan trust terhadap friendship quality pada Aremania. Teknik Purposive sampling digunakan penelitian ini dengan subyek sejumlah 126 Aremania memiliki kriteria pernah menonton langsung pertandingan sepakbola di stadion. Hasil penelitian diketahui bahwa terdapat pengaruh antara empati dan trust terhadap friendship quality pada Aremania dengan nilai F sebesar 33.173 dengan nilai signifikasi $0.000(\mathrm{p}<0.05)$. Empati dan trust memberikan pengaruh terhadap friendship quality sebesar 35\%. Empati dan trust yang tinggi pada Aremania dapat meningkatkan friendship quality pada Aremania dan masyarakat pada umumnya.
\end{abstract}

Kata Kunci : aremania; empati; friendship quality,trust . 
Psikoislamika: Jurnal Psikologi dan Psikologi Islam (JPPI) Volume 16. Nomor 1. Tahun 2019. Copyright @ 2019. Pusat Penelitian dan Layanan Psikologi.

\section{PENDAHULUAN}

Suporter sepak bola identik dengan perilaku agresivitas yang dipicu konflik antar suporter. Konflik yang terjadi pada suporter sepakbola dapat mengakibatkan kerugian materi dan korban jiwa. Di Indonesia sendiri sudah banyak korban jiwa yang melayang sia-sia, bahkan sejak tahun 1995 terdapat 63 korban meninggal karena kerusuhan yang terjadi antar suporter sepakbola (Firdausy, 2018, p. 1) . Selain itu juga, mayoritas berita memberikan informasi mengenai kerusuhan yang terjadi antar suporter namun selain konflik antar suporter, terdapat juga terjalinnya persahabatan yang kuat. Jika suporter berdamai tanpa bentrok akan memunculkan rasa persahabatan dan memperoleh dampak positif bagi klub yaitu pemasukan tiket suporter klub tamu (S., S., \& R., 2017, p. 1). Para suporter yang loyal akan mendukung dimanapun klub kebanggaannya bertanding baik kandang maupun tandang. Hal tersebut dapat dimanfaatkan untuk menarik minat suporter untuk bertandang dan mendukung klub kebanggannya. Kenyamanan dari suporter akan berdampak baik bagi berlangsungnya hubungan yang baik para suporter.

Hampir disetiap daerah di Indonesia terdapat klub sepakbola yang dimana terdapat pula suporter yang mendukung klub tersebut. Para suporter Aremania tidak hanya berasal daerah Malang saja, tetapi juga terdapat dari daerah lain juga tetapi menyukai klub Arema. Pada setiap kompetisi yang digelar, klub sepakbola akan bermain dikandang mereka dan bertandang ke daerah atau kota lain dan suporter yang loyal dengan klub kebanggaannya akan mengikuti klub tersebut berlaga walaupun jarak yang ditempuh sangat jauh. Friendship quality yang tinggi dapat ditunjukan dengan kegiatankegiatan dan perilaku positif yaitu dari saling membantu dan saling mengenal sesama suporter, perilaku negatif juga dari dua pihak rendah yaitu rendahnya konflik, persaingan dan perilaku negatif lainnya (Rahmat, 2014) . Perilaku tolong-menolong para suporter dapat dilihat dari bantuan yang diberikan fasilitas saat bertandang maupun sedang transit dikota tertentu ataupun membutuhkan tempat beristirahat dan konflik antar suporter yang rendah akan mengurangi pertikaian suporter.

Para suporter yang bersahabat akan membantu suporter yang mengalami masalah dan mencoba memberi dukungan moril jika mengalami keterpurukan. Persahabatan terjadi karena memiliki kedekatan dan menyukai satu sama lain serta akan memberikan bantuan yang dilakukan secara suka rela (Fauziah, 2014) .Terdapatnya Aremania dari luar wilayah Malang menjadikan perjalanan yang ditempuh oleh para suporter tersebut akan mengalami kesulitan dalam mendapatkan tempat istirahat ataupun kesulitan dalam mendapatkan tiket, dengan adanya persahabatan dari para suporter dapat membantu para suporter Aremania dari luar wilayah 
Malang untuk diberikan bantuan secara sukarela tanpa meminta imbalan. Bantuan tersebut sangat berguna menciptakan hubungan yang baik bagi para suporter untuk memberikan kondisi yang kondusif.

Empati dapat dijadikan untuk memahami masalah yang sedang dialami indvidu lain dengan menjunjung rasa toleransi, dapat dalam mengendalian diri, bersikap baik, berpengaruh dan memiliki sikap peduli dengan individu lain (Sari, Ramdhani, \& Eliza, 2003)

Beragamannya suporter Aremania juga terjadi beragamnya asal daerah dan budaya pada setiap individu dan kelompok suporter Aremania. Rasa saling menghargai dan toleransi diperlukan untuk mengurangi rasisme dalam setiap pertandingan sepakbola. Sebagai pelaku dan menjadi bagian dalam setiap pertandingan, suporter dapat mengendalikan diri tentang adanya gesekan yang mungkin akan terjadi kerusuhan. Perdamaian dan persahabatan yang terjalin antar suporter dapat menumbuhkan perasaan empati yang dapat meminimalir atau bahkan menghilangkan dampak negatif dari perbedaan tersebut.

Terbentuknya persahabatan pada antar individu terjadi karena adanya kebersamaan yang terjalin, sedangkan hal-hal yang mempengaruhi bertahannya persahabatan adalah ikatan emosional, kepercayaan, serta adanya perasaan saling membutuhkan

(Handayani, 2013) . Sehingga persahabatan yang terjadi pada suporter yang mampu bertahan karena terdapat kemampuan dalam memahami perasaan supoter lain. Selain itu juga timbulnya kepercayaan yang mampu menghilangkan prasangka sehingga persahabatan yang terjalin mampu terjalin dengan baik. Friendship quality suporter dapat ditinjau dari bagaimana perasaan empati dan kepercayaan yang diberikan pada sesama suporter. Adanya perasaan empati dapat memahami perasaan suporter lain dapat menumbuhkan friendship quality antar suporter. Trust dalam keyakinan dalam berhubungan dan saling mengerti satu sama lain dapat menjadikan Friendship quality yang baik. Terbentuknya persahabatan pada antar individu terjadi karena adanya kebersamaan yang terjalin, sedangkan hal-hal yang mempengaruhi bertahannya persahabatan adalah ikatan emosional, trust, serta adanya perasaan saling membutuhkan (Handayani, 2013) . Penelitian ini bermanfaat untuk mengetahui suporter tidak hanya dikenal negatifnya tetapi terdapat juga sisi positif yang ada. Variabel terikat (Y) pada penelitian ini merupakan friendship quality. Pada penelitian ini terdapat dua variabel bebas yaitu empati (X1) dan trust (X2).

\section{METODE PENELITIAN Rancangan Penelitian}

Pendekatan kuantitatif dilakukan dalam penelitian ini. Penelitian ini bertujuan untuk mengetahui adanya pengaruh empati dan trust terhadap friendship quality pada Aremania. Analisis yang digunakan penelitian pengaruh empati dan trust terhadap friendship quality yaitu analisis regresi.

\section{Subyek Penelitian}

Populasi dalam penelitian ini adalah supporter tim sepakbola Aremania. Populasi pada penelitian ini memiliki jumlah tak terhingga karena peneliti tidak dapat memastikan 
jumlah populasi dengan tepat. Sampling dalam penelitian ini menggunakan purposive sampling dengan kriteria yang ditetapkan peneliti adalah Aremania yang pernah melihat sepakbola secara lagsung. Peneliti mengambil sampel sebanyak 126 individu yang tergabung dalam supoter sepakbola Aremania dan pernah melihat pertandingan secara langsung.

\section{Teknik Pengumpulan Data}

Teknik pengambilan data dalam penelitian ini menggunakan skala. Skala yang digunakan berjumlah tiga buah untuk mengukur empati, trust, dan friendship quality dari subyek penelitian. Pengukuran friendship quality dilakukan dengan menggunakan Friendship Quality Scale yang disusun oleh Thien, Razak, dan Jamil (2012) yang terdiri 21 aitem dengan hasil valid berjumlah 20 aitem dengan daya beda sebesar 0.409 0.657. Instrumen yang digunakan untuk mengukur empati adalah The QCAE (Questionnaire of Cognitive and Affective Empathy) dari Reiners, Drake, Corcoran, \& Shryane (2011) yang terdiri dari 31 aitem, dengan 26 aitem yang valid dan daya beda dari skala Empati berkisar antara 0.316 sampai dengan 0.627. Skala trust yang digunakan pada penelitian ini adalah Trust Action Questionnaire dari Johnson \& Johnson (2014) yang terdiri dari 14 aitem, dengan 13 aitem yang valid daya beda skala Trust berkisar antara 0.489 sampai dengan 0.678. Berdasarkan hasil analisis reabilitas diketahui tiga instrument yang digunakan untuk penelitian reliabel karena memiliki koefisien Cronbach's
Alpha mendekati angka satu. Pada skala Friendship Quality memiliki koefisien sebesar 0.904. Skala Empati memiliki koefisien sebesar 0.900 . Serta pada skala Trust memiliki koefisien sebesar 0.905 .

\section{HASIL}

Tujuan analisis penelitian untuk mengetahui terdapatnya pengaruh empati dan trust terhadap friendship quality pada Aremania. Analisis hipotesis menggunakan analisis regresi linier berganda dengan metode stepwise bertujuan mengetahui variabel bebas yang dominan mempengaruhi friendship quality. Hasil analisis menunjukkan terdapat pengaruh empati dan trust terhadap friendship quality $(\mathrm{F}=$ $33,173 ; \mathrm{P}<0,05)$. Hal ini menunjukkan bahwa hipotesis mayor dalam penelitian ini diterima, artinya variabel empati dan variabel trust berpengaruh yang signifikan terhadap friendship quality. Adapun hasil uji parsial antar variabel dijelaskan pada tabel 1 : 
Tabel 1. Uji Pengaruh Empati dan Trust terhadap Friendship Quality dengan menggunkan Stepwise.

\begin{tabular}{llrrrrr}
\hline \multicolumn{1}{l}{ Model } & \multicolumn{1}{c}{$\begin{array}{c}\text { Sum of } \\
\text { Squares }\end{array}$} & df & $\begin{array}{c}\text { Mean } \\
\text { Square }\end{array}$ & F & Sig. \\
\hline 1 & Regression & 6064.821 & 1 & 6064.821 & 55.874 & $.000^{\mathrm{b}}$ \\
& Residual & 13459.536 & 124 & 108.545 & & \\
& Total & 19524.357 & 125 & & & \\
& Regression & 6841.245 & 2 & 3420.623 & 33.173 & \\
& Residual & 12683.112 & 123 & 103.115 & & $.000^{\mathrm{c}}$ \\
& Total & 19524.357 & 125 & & & \\
\hline
\end{tabular}

Tabel 2. Kontribusi Variabel Bebas terhadap Variabel Terikat.

\begin{tabular}{lllll}
\hline Model & R & R Square & $\begin{array}{l}\text { Adjusted } \\
\text { Square }\end{array}$ & $\begin{array}{l}\text { R Std. Error of } \\
\text { the Estimate }\end{array}$ \\
\hline 1 & .557 & .311 & .305 & 10.41848 \\
2 & .592 & .350 & .340 & 10.15454 \\
\hline
\end{tabular}

Berdasarkan tabel dijelaskan bahwa variabel empati memberikan kontribusi sebesar $\left(\mathrm{R}^{2}=0.311\right) 31,1 \%$. Sedangkan variabel empati dan trust terhadap friendship quality memiliki pengaruh sebesar $\left(\mathrm{R}^{2}=0.350\right)$. Artinya dalam variabel empati dan trust terdapat pengaruh terhadap friendship quality sebesar 35\%.

Tabel 3. Uji Parsial

\begin{tabular}{|c|c|c|c|c|c|c|c|}
\hline \multirow{2}{*}{\multicolumn{2}{|c|}{ Model }} & \multicolumn{3}{|c|}{$\begin{array}{c}\text { Unstandardized } \\
\text { Coefficients }\end{array}$} & \multirow{2}{*}{$\begin{array}{c}\text { Standardized } \\
\text { Coefficients } \\
\text { Beta } \\
\end{array}$} & \multirow[b]{2}{*}{$\mathrm{t}$} & \multirow[b]{2}{*}{ Sig. } \\
\hline & & B & Std. & Error & & & \\
\hline \multirow[t]{2}{*}{1} & (Constant) & 28.235 & & 6.378 & & 4.427 & .000 \\
\hline & EMPATI & .500 & & .067 & .557 & 7.475 & .000 \\
\hline \multirow[t]{3}{*}{2} & (Constant) & 25.207 & & 6.314 & & 3.992 & .000 \\
\hline & EMPATI & .348 & & .085 & .389 & 4.084 & .000 \\
\hline & TRUST & .356 & & .130 & .261 & 2.744 & .007 \\
\hline & Berdasarkan & tabel & 3 & \multirow{2}{*}{\multicolumn{4}{|c|}{$\begin{array}{l}\text { dan variabel trust }(\mathrm{t}=2.744 ; \mathrm{p}<0.05) \text {. } \\
\text { Sedangkan pada hipotesis minor yang } \\
\text { pertama diterima yaitu terdapat } \\
\text { pengaruh antara empati terhadap } \\
\text { friendship quality pada Aremania. } \\
\text { Hipotesis minor yang kedua juga }\end{array}$}} \\
\hline & $\begin{array}{l}\text { jukkan bahwa } \\
\text { tribusi sebesar } \\
\text { skan variabel tr } \\
\text { r }(\beta=0.261) \\
\text { el empati }(\mathrm{t}=\end{array}$ & $\begin{array}{l}\text { variabel e } \\
(\beta=0 \\
\text { ust berkont } \\
\text { Secara p } \\
\text { 7.475; p < }\end{array}$ & $\begin{array}{l}\text { pati } \\
557) \\
\text { busi } \\
\text { rsial } \\
.05)\end{array}$ & & & & \\
\hline
\end{tabular}


terdapat pengaruh antara trust Aremania.

terhadap friendship quality pada

Tabel 4. Hasil skor mean dan standart deviasi.

\begin{tabular}{lllll}
\hline Variabel & \multicolumn{2}{c}{ Hipotetik } & \multicolumn{1}{c}{ Empirik } \\
& Mean & $\begin{array}{l}\text { Standar } \\
\text { Deviasi }\end{array}$ & Mean & Standar Deviasi \\
\hline $\begin{array}{l}\text { Friendship } \\
\text { Quality }\end{array}$ & 60 & 20 & 75.4 & 12.5 \\
Empati & 81 & 27 & 94.4 & 13.9 \\
Trust & 39 & 13 & 48.6 & 9.2 \\
\hline
\end{tabular}

Variabel friendship quality memiliki skor mean empirik 75.4 dan skor mean hipotetik sebesar 60. Pada variable empati, skor mean empirik yang dimiliki sebesar 94.4 dan skor mean hipotetik sebesar 81. Variabel trust memiliki skor mean empirik sebesar 48.6 dan mean hipotetik sebesar 39. Sedangkan standar deviasi empirik yang dimiliki friendship quality, empati, dan trust lebih rendah daripada standar deviasi hipotetik. Standar deviasi hipotetik friendship quality sebesar 20 dan standar deviasi empiriknya sebesar 12.5. Variabel empati memiliki standar deviasi empirik 13.9 dan standar deviasi hipotetik 27. Pada variabel trust, standar deviasi empirik yang dimiliki sebesar 9.2 dan standar deviasi hipotetik yang dimiliki sebesar 13 .

\section{PEMBAHASAN}

Analaisi penelitian ini menggunakan program SPSS 22 for windows, dari hasil pengolahan data diketahui bahwa pengaruh empati dan trust terhadap friendship quality pada Aremania memiliki nilai $\mathrm{R}$ square 0.35 dan Signifikan $(F=33.173, p=0.00$ $<0.05)$. Sehingga empati dan trust memberikan pengaruh terhadap friendship quality pada Aremania sebesar $31.17 \%$.

Meningkatkan friendship quality dibutuhkan kecerdasan emosional untuk mempermudah individu dalam berinteraksi dengan individu lain. Individu dengan kecerdasan emosional akan memiliki sikap empati yang baik pula (Diantika, 2017) . Dalam friendship quality yang baik terdapat pula kepercayaan didalamnya. empati dan kepercayaan dapat mempengaruhi friendship quality menjadi lebih baik.

Friendship quality dapat diukur dari bantuan yang diberikan, pertukaran informasi, dan banyaknya konflik (Herlina \& Loisa, 2018). Empati seseorang dapat diketahui dalam memberi bantuan kepada orang lain, sementara itu kepercayaan dalam suatu hubungan dapat dilakukan saling bertukar informasi. Jadi, empati dan kepercayaan dapat menjadi mengukur tingkat kualitas dalam hubungan persahabatan.

Menurut Berndt (dalam Prayona, 2017) tingginya friendship quality diikuti dengan tingginya tingkat perilaku prososial, keakraban, dan ciri positif lainnya, serta rendahnya sifat negatif seperti konflik dan persaingan. Dalam perilaku prososial seorang individu terdapat empati yang kuat dan mempunyai kepercayaan satu sama lain. 
Hasil penelitian diketahui terdapat pengaruh Empati terhadap Friendship Quality dengan nilai R square 0.311 dan Signifikan $(\mathrm{F}=$ $55.874, \mathrm{p}=0.00<0.05)$. Sehingga empati memberikan pengaruh terhadap friendship quality pada Aremania sebesar 31,1\%. Sejalan dengan penelitian ini, pada penelitian yang dilakukan oleh Nursyahrurahmah (2018) terdapat hubungan yang positif yang signifikan antara friendship quality dengan empati. Dari hasil pengolahan data didapat nilai $\mathrm{R}$ square 0.155 atau sebesar $15,5 \%$. Penelitian ini memiliki nilai signifikan sebesar $0.070<0.05$, artinya penelitian ini mempunyai hubungan yang signifikan.

Hasil analisis data dalam penelitian ini menggunakan program pengolahan data SPSS 22 for windows, dari hasil pengolahan data diketahui bahwa pengaruh Trust terhadap friendship quality memiliki nilai $\mathrm{R}$ square 0.262 dan signifikan $(\mathrm{F}=$ 44.089, $\mathrm{p}=0.00<0.05)$. Sehingga trust memberikan pengaruh terhadap friendship quality pada Aremania sebesar $26,2 \%$.

Implementasi dari hasil penelitian ini pada masyarakat adalah memberi sudut pandang lain pada masyarakat bahwa suporter sepakbola tidak dominan pada sisi negatifnya tetapi terdapat juga sisi positif dari perilaku yang dilakukan oleh suporter sepakbola. Sisi positif dari suporter sepakbola dapat dilihat dari perilaku Aremania. Empati dan kepercayaan yang tinggi pada Aremania dapat meningkatkan friendship quality pada Aremania dan masyarakat pada umumnya.

Tetapi pada penelitian ini terdapat keterbatasan yaitu kurangnya waktu penelitian sehingga peneliti hanya memiliki subyek minimal. Selain itu hanya terkumpulnya subyek yang minimal memberikan dampak tidak mampu mencakup secara pasti jumlah Aremania. Peneliti juga mengalami hambatan dalam mencari subyek yang sesuai kriteria karena jumlah Aremania yang sesuai kriteria tidak diketahui secara pasti.

\section{KESIMPULAN}

Berdasarkan hasil penelitian dapat disimpulkan bahwa Aremania mempunyai tingkat friendship quality yang kuat. Friendship quality pada Aremania dipengaruhi oleh empati dan trust pada sesama Aremania. memberikan bantuan dan saling bertukar informasi dapat meningkatkan friendship quality. Friendship quality yang tinggi individu dalam kelompok suporter Aremania dapat lebih memahami satu sama lain sehingga dapat meningkatkan solidaritas dan kekompakan pada kelompok suporter Aremania.

\section{DAFTAR PUSTAKA}

Diantika, E. (2017). Hubungan Antara Kecerdasan Emosional dan Kualitas Persahabatan Pada Remaja Akhir. Jurnal Psikologi 10 (2), 167-173.

Fauziah, N. (2014). Empati, Persahabatan, dan Kecerdasan Adversitas pada Mahasiswa yang sedang Skripsi. Jurnal Psikologi Undip (13)1, 78-92.

Firdausy, F. (2018, September 09). Daftar Suporter Tewas Dalam 23 Tahun Terakhir. Retrieved Feburari 13, 2019, from 
www.goal.com:

https://www.goal.com/id/berita /daftar-suporter-tewas-dalam23-tahunterakhir/1f0zrfi1i4tyzzc 7 hwu $2 \mathrm{r}$ $\mathrm{p} 47 \mathrm{v}$

Handayani, I. (2013). Representasi Persahabatan dalam Film $5 \mathrm{Cm}$. Interaksi Online, 4 (4).

Herlina, \& Loisa, R. (2018). Analisis Dampak Kualitas Persahabatan Pada Peningkatan Kinerja Dan Kebahagian Di Tempat Kerja Generasi Milenial. Journal Of Communication Studies (3)2, 15-31.

Johnson, D., \& Johnson, F. (2014). Joining Together Group Theory and Group Skills. Edinbrugh Gate: Pearson.

Nursyahrurahmah. (2018). Hubungan Antara Friendship quality Dan Empati Dengan Kebahagian Pada Mahasiswa Bima. Jurnal Ecopsy (5)2, 88-93.

Prayona, B. A. (2017). Perbedaan Friendship quality Remaja Ditinjau dari Gaya Kelekatan. Skripsi, Malang: Universitas Muhammadiyah Malang.

Rahmat, W. (2014). Pengaruh Tipe Kepribadian dan Kualitas Persahabatan dengan Kepercayaan pada Remaja Akhir (Mahasiswa Psikologi Universitas Mulawarman) . Jurnal Psikologi, 2(2), 206-216.

Reniers, R. L., Corcoran, R., Drake, R., Shryane, N. M., \& Vollm, B. A. (2011). The QCAE: A Questionnaire of Cognitive and
Affective Empathy. Journal of Personality Assessment (93)1, 84-95.

S., O., S., G., \& R., S. (2017, September 28). Persahabatan Antarsuporter - Banyak Teman, Banyak Rezeki. Retrieved Januari 29, 2019, from Bolasport.com: https://www.bolasport.com/rea $\mathrm{d} / 311369950 /$ persahabatanantarsuporter-banyak-temanbanyak-rezeki?page $=$ all

Sari, A. T., Ramdhani, N., \& Eliza, M. (2003). Empati dan Perilaku Merokok di Tempat Umum . Jurnal Psikologi 2, 81-90.

Thien, L. M., Razak, N. A., \& Jamil, H. (2012). Friendship Quality Scale: Conceptualization, Development and Validation. Joint AARE APERA International Conference (pp. 1-14). Sidney: University of Sydney. 